\title{
Historical Origins of Military Sports in Yunnan Military Academy and Whampoa Military Academy
}

\author{
Meng Xiangkun \\ Ministry of General Education, Guangzhou Nanyang Polytechnic College, Guangzhou 510925, \\ China \\ 874832133@qq.com
}

Keywords: Yunnan Military Academy, Huangpu Military Academy, military sports.

\begin{abstract}
The Yunnan Military Academy and the Huangpu Military Academy held by Sun Yat-sen in Guangzhou are both famous military schools in modern China. The two military academies made important contributions to China's modern anti-imperialism and anti-feudalism and the subsequent anti-Japanese war. Especially, many famous anti-Japanese generals were trained from the two academies. In addition, the two academies also made corresponding contributions to the development of China's modern military physical education. From the perspective of history, this paper probes into the support and help of Yunnan Military Academy to the early military sports of Huangpu Military Academy from the aspects of military sports teachers and military sports thoughts.
\end{abstract}

\section{Yunnan Military Academy}

The Yunnan Military Academy, founded in 1909, is a military school with far-reaching military and political influence in the modern history of China. The Yunnan Army, with its teachers and students in the martial arts hall as its backbone, has shown great courage in the war of protecting the law, the country and the Anti-Japanese War, and has made important contributions to the cause of national liberation. The military and political values of the Yunnan Military Academy also include the spirit of internationalism, which has trained a number of military personnel for Vietnam, Korea and South Korea.

The military lecture hall of Yunnan army also has an important historical value in the development of modern sports in China. Modern sports are closely related to the military, such as gymnastics and formation training. By studying the history of military sports teaching in Military sports, it is found that Military sports contributed to the military sports teaching in the early days of the founding of Guangzhou Huangpu Military Academy, and established the Military sports in the modern sports history through the study. The historical value of Whampoa Military Academy in Guangzhou.

\section{Brief Introduction of Whampoa Military Academy in Guangzhou}

In 1924, Mr. Sun Yat-sen founded the Huangpu Military Academy with the active support and help of the Communist Party of China and the Soviet Union to save China from peril. Huangpu 
Military Academy is the first military academy in China to train revolutionary army cadres. It is customarily called "Huangpu Military Academy" because of its location in Huangpu, Guangzhou. Since its establishment, the Huangpu Military Academy has taken Sun Yat-sen's "Creating a Revolutionary Army to Rescue China's Peril" as its tenet, taken "love and sincerity" as its motto, trained military and political personnel to form a revolutionary army with Huangpu students as its backbone, carried out armed overthrow of imperialist and feudal warlords'rule in China and completed the National Congress. Revolution is the end. Huangpu's teachers and students made great contributions to the Chinese revolution and occupied a prominent position in the modern history of China. The old site of Guangzhou Huangpu Military Academy was listed as the third batch of national key cultural relics protection units by the People's Republic of China in 1988.

\section{The Influence of Technical Teaching of Yunnan Military Academy on Whampoa Military Academy}

\subsection{The support for Yunnan military academy by Whampoa army's lecture hall.}

In 1924, with the help of the Soviet Union, Mr. Sun Yat-sen established the Huangpu Military Academy to train the commanders of the revolutionary army. "In the thirteenth year of the Republic of China, the Premier founded the Huangpu Military Academy, and Chiang Kai-shek, the headmaster of the former military academy (note: Yunnan Army Lecturing Martial Arts Hall), Wang Boling, Lin Zhenxiong, Shuai Chong, Liu Yaoyang, and other cadres were successively assisted by Guangdong Province. Most of the other cadres were graduates of the military academy." "In 1924, theYunnan Military Academywas invited to assist the Whampoa Military Academy (June 1924). Ye Jianying and other teachers, with a group of officers and firearms, went to be deputy director of the Professors'Department to bring the advanced teaching mode of the martial arts of Yunnan Army to Huangpu Military Academy, and made active efforts for the beginning and early development of Huangpu Military Academy. Liu Yaoyang, Chief of Infantry, Lin Zhenxiong, Chief of Cavalry, and Shuai Chongxing, Chief of Engineering, were all high-caliber students who graduated from the fifteenth phase of the Wushu Lecture Hall, and the fifteenth phase was a brilliant period when the teaching of the Wushu Lecture Hall of the Yunnan Army reached its peak in history. According to the book "Communists and Huangpu Military Academy" published by Guangzhou Publishing House this year, Yunnan Army students who later became members of the Communist Party became at least five important instructors of Huangpu Military Academy after 1924. The 5 were Xie Jianying, Xu Chengzhang, Yan Fengyi, Yang Ning and Cui Yongjian. The following are introduced respectively. Ye Jianying, a native of Meixian County, Guangdong Province, was born in 1897 and enrolled in the 12th phase of the Yunnan Army Lecture Hall in 1917. In 1924, at the invitation of Liao Zhongkai, the Party representative of Huangpu Military Academy, she participated in the preparatory work of Huangpu Military Academy. She served as deputy director and instructor of the Professor's Department, and taught ordnance science. She was one of the Xu Chengzhang, formerly named Xu Tianzong, was born in 1892 in Qiongshan, Hainan Province. He entered the 12th stage of Yunnan Army Lecture Hall in 1917 and was appointed as a special officer and military coach of Captain Huangpu Military Academy in 1924. Yan Fengyi was born in 1896 in Qionghai, Hainan Province. Yang Ning, also known as Yang Lin, formerly known as Kim Hoon, was born in 1898. He was admitted to the 16th stage of the Yunnan Army Lecture Hall in 1922. He was appointed as a lieutenant instructor of the Huangpu Military Academy Student Corps in 1924. Captain of the team, then technical director of the military academy instructor, the rank of Lieutenant Colonel; Cui Yongjian, also known as Shiquan, was admitted to Yunnan Army in 1923, 17, 1925-1927 in Huangpu Military Academy instructor. 


\subsection{The influence of Zeng Hu Zhi Zhi Shu on the military academy in Yunnan, the spiritual textbook of the military lecture hall of the Yunnan army.}

At the beginning of the formal opening of Yunnan Army's Wushu School, Li Genyuan set the motto of "perseverance and diligence" for the teachers and students. His teaching focuses on "determination", "diligence" and "shame". His aim is to "defend the country and the people", so he attaches great importance to physical exercise in his mind. In order to guide the students in thinking, the Wushu Lecture Hall specially offered ethics and spiritual courses, and educated the students in thought, which made them realize that in order to protect their country and protect their country, they must study hard, exercise, and have a strong physique in order to kill the enemy and defend the country on the battlefield. Li Genyuan pointed out that "the sincerity of patriotism, the courage of the enemy, the righteousness of death and suicide, and the determination to be strong all require painstaking efforts to show one's strength of mind..." In 1911, Li Jingxi, governor of Yunnan and Guizhou, transferred Tsai e to Kunming. When Cai E arrived at Kunming, Li Jingxi did not use him in time. During the period of unemployment, Tong Zhong Lin, a new army town in Yunnan, asked Cai E to prepare a "spiritual speech" for the new army. As Cai Ying-hyun witnessed the so-called "new army" still demoralized, the decline of Ji Gang, "the foundation has been bad, to restore the remedy, by no means one or two can make a success of it." He felt that only when he called on "most gentlemen of one heart and one virtue to maintain and agitate with each other" and "volunteer to save the country for the purpose of death" could he "cross the bitter sea of compatriots and put the country on a smooth road", and he readily agreed. He selected Zeng Guofan and Hu Lin-yi's theory of governing the army, compiled the book "Zeng Hu Zhibing Quotations" and added comments after each chapter to elucidate his military thinking, aiming at enforcing the army and expelling the great powers. The first ten chapters of Zeng Hu's Analects of Administering Soldiers include material, personnel, aspiration, honesty, courage, strictness, justice, benevolence, diligence and harmony. We must be cautious in choosing and be prepared for both intelligence and bravery. This book is a compulsory course for Yunnan army's lecture hall.

\section{Conclusion}

The research work of history is mainly through the possession of a large number of first-hand literature, by consulting the relevant literature, from the historical literature analysis, sorting out the relevant research content, in logical analysis, reasoning integration, so as to achieve the goal of research. Although this paper has some valuable first-hand literature, but the difficulties are still highlighted; first of all, the continuity of time is not strong, there is a time data gap, can not fully reflect the whole teaching process of Military sports and the impact on Guangzhou Huangpu Military Academy; and then the lack of direct relevant information, even if it is not strong. Indirect literature, but also very little on the direct discussion of sports, so from the sports history of Yunnan Military Academy 1 on the impact of sports education in Guangzhou Huangpu Military Academy should continue to excavate historical data.

\section{References}

[1] Department of Army Coaches. Articles of Association of Yunnan Army Lecturing Martial Arts Hall.

[2] is unknown. The constitution of the Yunnan army martial arts school is unknown (unknown). During the period of the Republic of China, the Yunnan provincial library was hidden in.

[3] New edition of Leming, Shunning. Preliminary draft of Yunnan Military Science Education History: (unknown) :( unknown). Publication date is unknown.

[4] Ma Ji hole. History of Yunnan army's lecture hall: Kunming: Yunnan Nationalities Press, 1993.

[5] Wang Huiqiang. Secret history of Whampoa Military Academy. Qinghai people's publishing house, 1997. 
[6] Tang Han Qing. The historical picture scroll of Yunnan in the war of resistance against Japan. Kunming: Chenguang publishing house, 2005:157.

[7] Xie Ben Shu.Yunnan Military Academyhas important influence on Whampoa military academy. Yunnan archives, 2004, (06).

[8] Su Jing Cun. History of modern Chinese School Physical Education. Beijing: People's education press, 1994.

[9] Kunming sports chronicles Compilation Committee. Kunming sports chronicles. Kunming: Yunnan Nationalities Press, 2002. 